\title{
DEVELOPMENT OF A LEARNING MODULE USING CONSTRUCTIVE ALIGNMENT THEORY IN PROJECT MANAGERIAL COURSE
}

\author{
Lisa Indriati ${ }^{1 *}$; Christian Anggrianto ${ }^{2}$ \\ ${ }^{1,2}$ Visual Communication Design, School of Creative Industry, Universitas Ciputra Surabaya \\ CitraLand CBD Boulevard, Made, Kec. Sambikerep, Kota Surabaya, Jawa Timur 60219, Indonesia \\ 1'lisa.indriati@ciputra.ac.id; ${ }^{2}$ christ.ang@ciputra.ac.id
}

Received: $23^{\text {rd }}$ April 2021/ Revised: $30^{\text {th }}$ June 2021/ Accepted: $14^{\text {th }}$ July 2021

How to Cite: Indriati, L. \& Anggrianto, C. (2021). Development of a learning module using constructive alignment theory in project managerial course. Humaniora, 12(3), 255-260.

https://doi.org/10.21512/humaniora.v12i3.7304

\begin{abstract}
The research intended to develop an ideal learning module using constructive alignment theory on Project Managerial course. It seemed difficult to draw firm conclusions about constructivism due to the various interpretations both pedagogically and epistemically. The mixed-method was used to survey 56 students participating in the Project Managerial course. Moreover, qualitative methods were implemented for deeper analysis. The methods provided an overview of the students' level of understanding of the material, what they can do at the end of the lesson, as well as learning activities that can help students be actively involved in class. It was also to find out whether students have achieved the expected outcomes. The results prove that students' understanding of the Project Managerial course is good, with an average score of 59,80 before the test and 85,88 after the test $(n=56)$. Students' feedback shows that group assignment remains lacking of students 'participation with an average value of 3,4. In every relationship between the client and the designer, there are more or less the same systematic phases so that the results can be consistent. Different designers may have different terms. The research provides a big picture of the ideal design project management pattern. Whatever term is used later, of course, every successful design project must be managed properly and consistently.
\end{abstract}

Keywords: constructive alignment, learning module, project managerial course

\section{INTRODUCTION}

As the World Health Organization (WHO) declares, the global pandemic has changed the way for people to do activities and learn. Many sectors affected by this pandemic result in zero industrial outcomes, increasing inflation, significant unemployment, and declining living standards, which are projected to add a few more millions of people to poverty (Grima et al., 2020). Amidst all of this turmoil and chaos, there are many opportunities to reform, including in the education sector. Innovation and technological advancement and public willingness to accept these disruptions are the reason for optimism to make the situations recover faster.

Despite the tough situations, students need to think critically and graduate with sets of soft skills that can enhance their employability (Croy, 2018). To achieve both, it is necessary to combine outcomes and approaches in teaching. However, the biggest challenge in educational institutions for now is figuring out how to manage the educational process without causing too much change to the students and instructors. The government continues to innovate in learning programs to improve the quality of education in Indonesia.

Constructivism has become a common reference point for educational study, curriculum development, and suggested pedagogy in education. It is a concept often used in educational and broader social science discourse, though it has a variety of definitions and connections relating to various 
educational philosophies, research epistemology, cognitive growth, learning theory, and pedagogical approach (Taber, 2019).

Constructivism has been linked to philosophical and sociological stances that have challenged conventional conceptions of the essence of public knowledge and its "development". As a result, the simplistic understanding of the origin and development of scientific knowledge is questioned by scholarly work in the philosophy of science and by popular culture. However, the sociological of information, with its emphasis on the social construction of (what is taken to be) meaning in particular cultural contexts, is becoming increasingly important, which has brought the social and structural dimensions of information development to light.

Discussions about the essence of canonical knowledge and how it is obtained can be relevant for fundamental educational issues such as the meaning of schooling and the structuring and selection of curriculum. However, constructivism as a learning perspective with implications for teaching canonical knowledge is the type of constructivism that has arguably had the most influence on classrooms around the world. The research particularly investigates constructivism in an unconventional environment related to social studies such as design education.

The research focuses on developing an ideal learning module using constructive alignment theory on the Project Managerial course Visual Communication Design Universitas Ciputra (VCD UC). Great graphic design does not just happen magically. It is the result of good collaboration between designer and client. To produce a good collaboration, it is necessary to have the ability to manage a team consisting of various personalities, skills, and expertise. A successful design can attract, persuade, motivate, and please the target market. This can be achieved through effective planning, organization, and management. Thus, it is necessary to implement a guide to help students understand and use best practices in design management to bring design concepts through successful completion.

The constructive alignment theory acknowledges the importance of connecting the new subject information to the learner's previous concepts and experiences. Learning entails the acquisitions of new information and the modification of students' perspective and understanding of previously acquired knowledge. The instructor must comprehend the student's perspectives and viewpoints to challenge students' way of thinking (Croy, 2018).

Learning activities are planned to provide learning experiences that involve mental and physical processes through interactions between students, students and lecturers, the environment and other learning resources to achieve learning outcomes (Rusman, 2017). Learning that involves students will provide more learning experience, so the planned learning outcomes can be realized (Sidek \& Yunus, 2012).
Learning outcomes to meet the minimum criteria for graduate ability, including attitudes, knowledge, and skills can be carried out effectively if supported by management (Manullang, 2014). Management is a series of activities directed at organizational resources (human, financial, physical, and information) to achieve organizational goals efficiently and effectively (Griffin et al., 2004). In addition, management manages a job to get results to achieve predetermined goals by moving other people to work (Herujito, 2010).

The learning process is a relatively permanent behaviour change in a person due to experience or training involving physical and psychological aspects, so a person can develop their knowledge and skills gradually (Syarifuddin, 2011). The learning process can determine the student's perspective since it is influenced by the interaction between the learning environment and learning as a process of self-adjustment; with self-adjustment, there will be changes in students.

Appropriate learning can provide significant impact for students to: 1) develop creativity, critical, and analytical thinking; 2) identify and apply the learning materials precisely; 3) improve the ability in constructing new knowledge to enhance a good mastery of the learning material; 4) improve students' ability to understand clinical problems; and 5) improve communication and teamwork skills (Zakaria \& Awaisu, 2011).

The learning process is a planned activity arranged by the lecturer so that students can learn and achieve the expected competencies. Therefore, before carrying out learning, the lecturer must compile a learning plan, which is a set of plans and arrangements for learning activities (Maria \& Sediyono, 2017)

Learning will become discontinuous if this change does not occur. A teaching theory that links teaching, students, and subject material through an overarching structure is needed to achieve deeper learning. To ensure that students change their understanding, teaching should be collaborative by involving the discovery of student misunderstandings, interventions to correct them, and the development of an engaging learning environment. The instructor directs the approaches use by focusing on the core topics that state the constraints to students learning, the material to be learned, and student learning problems. Theory three combines a more profound learning approach, continuous skill development, and various teaching strategies to facilitate learning (Ramsden, 2016).

As seen in Figure 1, the theory of positive alignment is the underpinning concept in curriculum design and development in higher education for devising teaching, learning experiences, and evaluation tasks to achieve intended learning outcomes. Deep learning is crucial for students, which becomes the duty of the curriculum developer to ensure that there is a balance between formative and summative evaluation (Ali, 2018). 

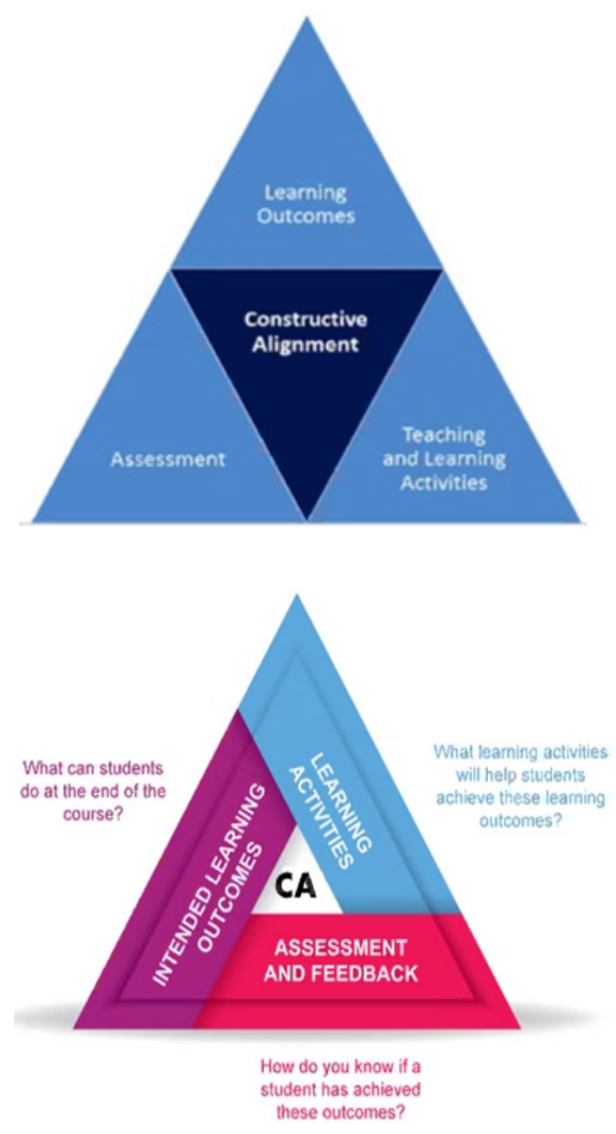

Figure 1 Constructive Alignment (Briggs, 1991)

Instructors needed to establish a constructively aligned curriculum in which learning outcomes are aligned with the teaching environment and develop a learning program focused on constructivist learning theory. Figure 1 shows the three steps involved in the constructive alignment process, which are: 1) determining learning outcomes; 2) selecting teaching/ learning activities that most likely contribute to the achievement of learning outcomes; and 3) assessing learning outcomes and how they fit (Biggs, 2001).

In every relationship between the client and the designer, the systematic stages are more or less the same so that the results can be consistent. Different designers may have different terms. This module aims to provide students with an overview of the ideal design project management pattern. Every successful design project must be managed properly and consistently, so students are ready to meet clients with all kinds of characters or instructions.

The result of this module shows that students can solve various industrial problems from the point of view of visual communication design by applying basic principles, visual communication design methods through research, exploration, and ideation to be communicated both verbally and visually, as well as principles of project management and preparation of supporting documents for clients.

The research is expected to provide an overview to the teacher when applying constructive learning theory to the learning process. In addition, by using examples in Project Managerial course, it is expected that design lecturer understand how the application of this theory can help to find appropriate learning activities and understand whether learning outcomes have been achieved. In addition, it also provides an overview of what students have learned at the end of the course.

\section{METHODS}

The research applies mixed methods, in the form of a quantitative survey of 56 students participating in the Project Managerial course. Furthermore, the research implements the qualitative method by interviewing all students registered to the class. The methods provide an overview of the students' level of understanding on the material, what they can do at the end of the lesson, what learning activities can help students be actively involved in class, and students' achievement based on the expected outcomes. The survey is conducted at the end of semester 2020.

Data analysis uses the procedure introduced by Braun and Clarke (2019) to analyze and interpret themes through the lens of Ackerman's learning mechanism. The thematic analysis is chosen because of its versatility. It is recursive methods that allow the researcher to switch between stages of analysis as needed. It allows for more in-depth analysis of the students' understanding of the examined phenomenon, as well as holistic responses, different interpretations of students' experiences (Miles et al., 2013).

Constructive alignment is often promoted as a principle for improving learning efficiency, but the student viewpoint is frequently overlooked when investigating its effect on student learning. As a result, more research is needed into how students' interactions with the various elements of positive alignment affect their learning style. To find out more about activities in the class that can improve learning, interviews are conducted with students. The results are used as input in designing the next class activity. After describing the learning outcomes and conducting assessments and discussion, a survey was also conducted to determine the level of student satisfaction with the Project Managerial course.

\section{RESULTS AND DISCUSSIONS}

Currently, the most common problem that visual communication design graduates deal with is their lack of ability to manage projects and businesses. The technology development that provides convenience for modern society seems to be an obstacle for young designers in exploring design concepts. Designers often only look at references from the internet and make slight changes to the design so that it does not have a strong characteristic or use templates for designing. In addition, most of them also do not have 
sufficient skills in translating client needs into designs.

Ideally, designers work as a problem solver; but design graduates are often not well-equipped with adequate skills to manage projects. It causes many graduates having difficulty in applying for a job at the company, making pricing and quotation, establishing long-term relationships with clients, and scaling up business. The Project Managerial course aims to provide design students with experience in the real world of work conditions, so that special methods are required to achieve them.

Evaluation aims at learning outcomes and learning process. Evaluation of learning outcomes emphasizes information about the acquisition of student outcomes in achieving learning objectives while learning evaluation is a process of obtaining information about the effectiveness of the learning process in helping students achieve learning goals optimally (Dimyati \& Mudjiono, 2013. Evaluation of learning outcomes is carried out by lecturers by utilizing the results of the assessment process and interpreted based on the rules to determine the level of student ability (Ismanto, 2014).

The learning model previously used was at the learning implementation stage based on the lecturer-centred learning model. Learning outcomes are limited to the level of students understanding and explaining the content of learning so that the competence of graduates focuses more on the realm of knowledge. Thus the model used is more inclined to a lecturer-centred learning model. The solution that can be applied is in the form of development at the learning planning stage, where the formulation of the competence of graduate courses is adjusted to the needs of the industrial world today.

The learning outcomes have been described in the semester course design (Rancangan Pembelajaran Semester/RPS) and an assessment rubric and explained in the first week of class. Students get an understanding of the expected achievements during the Project Managerial course.

The learning outcome of this course is: "Students have the knowledge to solve various industrial problems from the point of view of visual communication design by applying basic principles, visual communication design methods, through research, exploration and ideation to be communicated both verbally and visually, as well as principles of project management and preparation of supporting documents."

Based on the learning outcomes, it is divided into two sub-learning outcomes to make it easier for students to determine personal learning targets. In the stages, the evaluation is also carried out through assessments given to determine the level of student understanding of the materials given. The process is described in Figure 2.

The assessment results prove that students' understanding of the Project Managerial course is good, with an average score of 59,80 before the test and 85,88 after the test $(n=56)$. The students' feedback shows that group assignments still lacks of students' participation with an average value of 3,4.

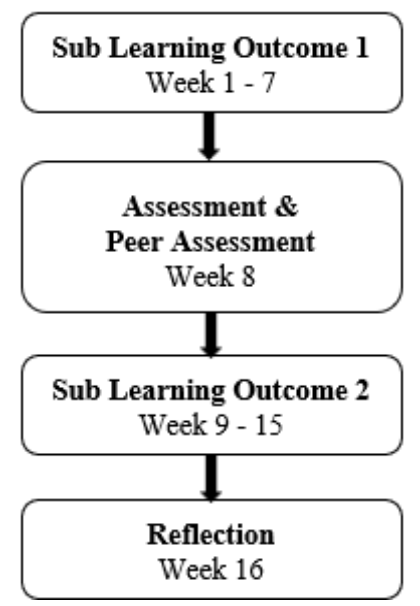

Figure 2 Constructive Alignment Process on Project Managerial Course

The attitudes of students and their approaches to learning are investigated. The findings reveal that various aspects of positive alignment play a significant role in driving student learning. Teaching and assessment-related factors appear to be important in guiding student learning and research. The interview finds that students feel less motivated by the learning process and group work activities. Most of the group's performance has not been optimal due to lack of understanding and collaboration between peers, thus designing learning activities can increase student motivation.

When asked for self-reflection on the contribution made to the group, the students have an average rating of 4,14 with various comments. The students are willing to contribute to the assignments given, do it on time, and provide ideas for group members. The other students point out that they are always present for group assignments to help with several things and provide ideas. However, they still have difficulties in understanding some material such as the ones related to budgeting or prices, so their contribution to assignments related to those materials is lacking.

Other comments are relatively the same. They contribute to making assignments and doing their part in the distribution of tasks. However, some assignments are late for submission since students are confused with the task distributions. The other group leader point out that their ability to share tasks with group members is quite good, but communication with team members is lacking, especially when they call to discuss the task due to bad connections and other distractions.

The inconsistent time when uploading the files on eLearn also becomes one of the causes of students being not engaged in learning activities. However, generally students think that they have the initiatives to provide ideas or concepts and manage the team's 
workflow to carry out the task according to the schedule. They also can take part as the supporter of the group so that the tasks can be done effectively and efficiently.

It can be concluded that students can manage the team and contribute well, but often lose motivation and experience confusion in distributing assignments to the teammates. Therefore, it is necessary to carry out activities that can support students in actively collaborating and participating in class. The sub learning outcome 2 performs collaborative activities such as utilizing the Miro and Trello platforms to accommodate the lack of motivation. In addition, extra points are also given from quiz results through Quizzes. This is proven to increase students' motivation by asking more questions and discussing in class compared to the previous half-semester. The results of the reflection prove that students are sufficiently engaged with the Project Managerial course. The student satisfaction survey, as seen in Table 1, shows that the students are quite satisfied with the course activities, where $60 \%$ of students are satisfied and $28,5 \%$ of them are very satisfied.

Table 1 Students' Course Satisfaction Level

\begin{tabular}{ccccc}
\hline No & Points & Frequency & $\mathbf{\%}$ & Category \\
\hline 1. & 5 & 16 & 28,58 & Very Good \\
2. & 4 & 34 & 60,71 & Good \\
3. & 3 & 5 & 8,93 & Average \\
4. & 2 & - & & Bad \\
5. & 1 & 1 & 1,78 & Very Bad \\
\hline \multicolumn{2}{r}{ Total } & $\mathbf{5 6}$ & $\mathbf{1 0 0 , 0 0}$ & \\
\hline
\end{tabular}

It shows that the Project Managerial course module is suitable for learning. Students have the knowledge to solve various industrial problems from a visual communication design point of view. They also have the ability to apply basic principles and visual communication design methods. The research finds that it is essential for exploration and ideation to be communicated both verbally and visually to clients. Therefore, students can carry out the principles of project management and prepare supporting documents for their clients.

In terms of the quality of learning, students give an average score of 4,36 and agree that this learning is quite beneficial for their careers in the creative world going forward. Some comments from students include that they learn an overview of how to manage a creative team. They agree that the course provides a lot of insight into the real world of work which can be applied in the future. The other students also think that the course provides a lot of insight into the stages or the most suitable steps to create a design project. The Project Managerial course allows students to know the conditions of the design industry and how to deal with clients. In addition, many new things need to be considered when creating a project, from the work system to determining the price.

The course also teaches practical things that will be necessary for the students' future. They learn about how to manage people to be able to work on a project together effectively. Students can also learn from the experiences when they have to interview an established design agency and use the information to create their design studio. This course forms a character as 'creativepreneur', not only design skill but also self-management. Young designers' most common mistake when handling clients is their lack of knowledge, experience, and sensitivity. Through this course, students learn how to hone their skills regarding project management and communication skills.

Generally, students think that Project Managerial is significantly useful as they can learn to understand: 1) the dynamics of working projects in a group; 2) the importance of communicating and building a relationship with clients and fellow team members; and 3) the need for good coordination and a clear system. Students learn the process to get the most out of it, and be able to handle projects professionally and solve any problem that may arise.

Since many students also want to have their own business, which will definitely have a team, they can learn various things about teams, workflow, negotiation, and many other useful things from this course. Project Managerial course provides material related to the professional world in real and applicable that can be used by students in their future jobs. This course can actually provide guidance to students to focus more on building their own design studio and portfolios with experiences gained from learning activities in class.

\section{CONCLUSIONS}

The implementation of learning results from a combination of several components that have their respective functions to achieve the expected learning objectives. Learning is a system that has learning components interrelated with each other to achieve learning objectives. The learning component consists of learning objectives, learning resources, learning strategies, learning media, and learning evaluation.

The implementation of the Project Managerial module will improve the quality of graduate students. Students who take the Project Managerial course will have project managerial guidelines. Students as designers are able to compile projects with maximum quality effectively, which can be applied to any design studio. In addition, designers can design contracts or make agreements with clients in accordance with the project being carried out. Miscommunication between designers and clients often occurs. Designers often misunderstand the desires of clients. Therefore with Project Managerial, the designer can cultivate 
the client's creative direction, and the problems that become the client's attention. The designer can decide and know the techniques, the media that will be used for the project delivery, and the final result of the design project. Thus designers can communicate their designs, provide recommendations to clients, and accept all designer suggestions. In the end, the designer can increase the profit on his design project.

In a designer-client partnership, there are more or less formal phases that must be followed for consistent results. This module aims to provide a broad overview of the ideal design project management pattern and train students, so they are ready to become designers, enter the design industry, and handle a client project. With this module, every young designer can use any existing terminology or whatever terms are used later. Every good design project must be controlled and managed consistently well.

From the course, 56 students are divided into 13 small groups; at least 2 groups continue the project in class to become a real business. They make an actual design studio and a photography agency. The output of the course are used to make offers to their prospective clients, such as company profile, portfolio books, quotation template, contract draft, etc. However, not all courses in the design department are suitable for applying constructive learning methods, thus further research is needed on this matter.

\section{REFERENCES}

Ali, L. (2018). The design of curriculum, assessment and evaluation in higher education with constructive alignment. Journal of Education and E-Learning Research, 5(1), 72-78. https://doi.org/10.20448/ journal.509.2018.51.72.78.

Biggs, J. (2001). The reflective institution: Assuring and enhancing the quality of teaching and learning. Higher Education, 41(3), 221-238. https://doi. org/10.1023/A:1004181331049.

Braun, V., \& Clarke, V. (2019). Reflecting on reflexive thematic analysis. Qualitative Research in Sport, Exercise and Health, 11(4), 589-597. https://doi.org/ 10.1080/2159676X.2019.1628806.

Briggs, L. J. (1991). Instructional design: Principles and applications. Educational Technology.

Croy, S. R. (2018). Development of a group work assessment pedagogy using constructive alignment theory. Nurse Education Today, 61, 49-53. https:// doi.org/10.1016/j.nedt.2017.11.006.

Dimyati, \& Mudjiono. (2013). Belajar dan pembelajaran $\left(5^{\text {th }}\right.$ Ed.). Jakarta: Rineka Cipta.
Griffin, R. W., Gania, G., Kristiaji, W. C., \& Medya, R. (2004). Management ( $7^{\text {th }}$ Ed.). Jakarta: Erlangga.

Grima, S., Dalli-Gonzi, R., \& Thalassinos, E. (2020). The impact of COVID-19 on Malta and its economy and sustainable strategies. Journal of Corporate Governance, Insurance and Risk Management, 7(1), 53-73. https://doi.org/10.51410/jcgirm.7.1.5.

Herujito, Y. M. (2010). Dasar-dasar manajemen (5 $5^{\text {th }}$ Ed.). Jakarta: Grasindo.

Ismanto, I. (2014). Evaluasi hasil belajar Pendidikan Agama Islam (PAI). Edukasia: Jurnal Penelitian Pendidikan Islam, 9(2), 211-235. https://doi.org/10.21043/ edukasia.v9i2.773.

Manullang, M. (2014). Manajemen pembelajaran matematika. Jurnal Pendidikan dan Pembelajaran, 21(2), 208-214.

Maria, E., \& Sediyono, E. (2017). Pengembangan model manajemen pembelajaran berbasis TIK di sekolah dasar. Kelola: Jurnal Manajemen Pendidikan, 4(1), 59-71. https://doi.org/10.24246/j.jk.2017.v4.i1.p5971.

Miles, M. B., Huberman, A. M., \& Saldana, J. (2013). Qualitative data analysis: A methods sourcebook. California: SAGE Publications.

Ramsden, P. (2016). Theories of learning and teaching and the practice of excellence in higher education. Higher Education Research \& Development, 12(1), 87-97. https://doi.org/10.1080/0729436930120108.

Rusman. (2017). Belajar \& pembelajaran berorientasi standar proses pendidikan. Jakarta: Kencana.

Syarifuddin, A. (2011). Penerapan model pembelajaran cooperative belajar dan faktor-faktor yang mempengaruhinya. Jurnal Pendidikan Islam, 16(1), 113-136. https://doi.org/10.19109/td.v16i01.57.

Sidek, E. A. R., \& Yunus, M. M. (2012). Students' experiences on using blog as learning journals. Procedia - Social and Behavioral Sciences, 67, 135143. https://doi.org/10.1016/j.sbspro.2012.11.314.

Taber, K. (2019). Constructivism in education: Concepts, methodologies, tools, and applications. In I. Management Associations (Eds.), Early Childhood Development: Concepts, Methodologies, Tools, and Applications (pp. 312-342). https://doi. org/10.4018/978-1-5225-7507-8.ch015.

Zakaria, S. F., \& Awaisu, A. (2011). Shared-learning experience during a clinical pharmacy practice experience. American Journal of Pharmaceutical Education, 75(4), 1-6. https://doi.org/10.5688/ ajpe 75475 